\title{
МЕТОД МОДЕЛЮВАННЯ КОМУНІКАТИВНИХ СИТУАЦЙ ЯК ЗАСІБ ФОРМУВАННЯ У ЗДОБУВАЧІВ ОСВІТИ ЖИТТЕВИХ КОМПЕТЕНТНОСТЕЙ
}

\author{
Кулик О. Д. \\ доктор педагогічних наук, дочент, \\ професор кафедри української лінгвістики і методики навчання, \\ дочент кафедри професійної освіти \\ Університет Григорія Сковороди в Переяславі \\ вул. Сухомлинського, 30, Переяслав, Київська область, Україна \\ orcid.org/0000-0001-9116-4403 \\ olenakulyk@gmail.com
}

\begin{abstract}
Ключові слова: методи навчання, культура мовлення, здобувачі освіти, майбутні вчителі/викладачі/педагоги, професійні стандарти, загальні компетентності.
\end{abstract}

У статті обгрунтовано переваги використання методу моделювання комунікативних ситуацій під час навчання здобувачів вищої освіти. Авторка доводить, що означений метод орієнтує здобувачів освіти на розвиток життєвих компетентностей та соціальної інтеграції, адже сприяє активізації мовлення, формує вміння вступати в мовленнєвий контакт $з$ іншими, досвід швидко орієнтуватися в невизначеному, непрогнозованому перебігові комунікації, самостійно застосовувати комунікативний досвід в інших сферах життєдіяльності, підвищує рівень культури фахового мовлення та ін. На конкретних прикладах унаочнює можливості широкого застосування означеного методу в процесі підготовки майбутніх педагогів/учителів/викладачів до фахової діяльності на прикладі викладання дисциплін «Комунікативні процеси в педагогічній діяльності» та «Культура професійного мовлення», що можуть бути як обов'язковими, так і вибірковими компонентами для здобувачів освіти, що отримують кваліфікацію вчителя/викладача/ педагога (за спеціалізаціями). Зроблено висновок, що під час систематичного виконання завдань, які моделюють життєві, зокрема й фахові, реалії, за використання методу моделювання комунікативних ситуацій як основного у взаємозв'язку 3 допоміжними (у дослідженні - методи інструктажу, гіпотез, прогнозування, бесіди, імітаційний, смислового бачення й аргументування, аналогії, класифікації, демонстрації відеоматеріалів, спостереження, діалогування, дискусії) здобувачі освіти, по-перше, долають страх виступу перед аудиторією (оскільки обговорення тієї чи тієї ситуації відбувається щоразу в групі за наявності протилежних поглядів на вирішення певної проблеми); активізують мовлення; автоматизують орієнтування у невизначеному, непрогнозованому перебігові комунікації; уможливлюють набуття комунікативного досвіду; підвищують рівень культури фахового мовлення; по-друге, розвивають такі операції мислення, як аналіз, синтез, порівняння, абстрагування, узагальнення, систематизація, конкретизація, простеження зв'язків, класифікація; по-третє, стимулюють креативність тощо. 


\title{
THE COMMUNICATIVE SITUATION MODELING METHOD AS A MEANS OF DEVELOPING LIFE COMPETENCIES IN EDUCATION APPLICANTS
}

\author{
Kulyk O. D. \\ Doctor of Pedagogical Sciences, Associate Professor, \\ Professor at the Ukrainian Linguistics and Teaching Methods Department, \\ Associate Professor at the Vocational Education Department \\ Hryhorii Skovoroda University in Pereiaslav \\ Sukhomlynskoho str., 30, Pereiaslav, Kyiv region, Ukraine \\ orcid.org/0000-0001-9116-4403 \\ olenakulyk@gmail.com
}

Key words: teaching methods, culture of speech, education applicants, future teachers/lecturers/educators, professional standards, general competencies.

\begin{abstract}
The article substantiates the advantages of using the communicative situation modeling method in the training of applicants for higher education. The author shows that the specified method guides education applicants to the development of life competencies and social integration, as it promotes speech activation, forms the ability to enter into speech contact with others. It gives the education applicants the experience to navigate quickly in an uncertain, unpredictable flow of communication, independently apply communicative experience in other spheres of life, increases the culture of professional speech and the like. Using specific examples, the author clearly demonstrates the possibility of broad implementation of the above method in the preparation of future educators / teachers / lecturers for professional activities based on the example of teaching the following disciplines «Communication processes in pedagogical activity» and «Culture of professional speech». They can be both mandatory and optional components for education applicants who receive the qualification of a teacher / lecturer / educator (by the specialization). The author concludes that during the systematic task performance, which simulate life, including professional realities, when using the communicative situation modeling method as the main in relationship with supporting (in the study - methods of instruction, hypotheses, prediction, conversation, simulation, semantic vision and argumentation, analogy, classification, video demonstration, observation, dialogue usage, discussion) education applicants: firstly, overcome the fear of speaking in front of an audience (since the situation discussion takes place every time in a group with opposite views on a certain problem solution); activate speech; automate orientation in an uncertain, unpredictable course of communication; make the acquisition of communicative experience; increase the culture of professional speech; secondly, develop such thinking operations as analysis, synthesis, comparison, abstraction, generalization, systematization, concretization, tracing connections, classification; thirdly, stimulate creativity and the like.
\end{abstract}

Постановка проблеми. У науковій літературі питання методів навчання висвітлено досить широко. Не вдаючись до їх глибокого аналізу, зауважимо, що підгрунтям авторських класифікаційних систем $є$ групування методів за різними критеріями: логікою передачі та сприймання навчальної інформації; цілісністю підходу до процесу навчання й методів навчання; основними дидактичними цілями; джерелами одержання знань; характером пізнавальної діяльності; етапами навчання й т. ін. Незважаючи на, здавалося б, вичерпне віддзеркалення науковцями означеного питання, в аспекті потрактування методів педагогами/вчителями/викладачами спостерігаємо хаос, невизначеність, невідповідність назв, змісту, підміну понять «метод», «прийом», «підхід», «технологія» та ін.

Упродовж багатьох років учені-дидакти й лінгводидакти намагаються увідповіднити й урівноважити систему спеціальних номінацій 3 мовною практикою фахівців в освітній/педагогічній галузі, однак «...хаос у терміносистемі, - за влуч- 
ним висловленням Н. Голуб, - явище досить типове, спричинене почасти несформованістю цілісного бачення іï у розрізі конкретної проблеми чи в загальнонауковому контексті» [1, с. 2]. Чим більш вичерпно науковці намагаються потрактувати й скласифікувати методи навчання (зокрема, автори практично кожної дисертаційної праці, монографії, що стосуються теорії та методики навчання (з галузей знань) як у закладах загальної середньої, так і вищої освіти, пильну увагу приділяють питанню методів навчання: зокрема, у межах нашого дослідження, теорія та методика навчання української мови в 33СО - 3. Бакум, О. Горошкіна, Т. Груба, С. Караман, О. Кулик, I. Кучеренко О. Кучерук, Л. Мамчур, В. Нищета, С. Омельчук, Е. Палихата, М. Пентилюк, І. Хом'як та ін.; теорія та методика навчання української мови в ЗВО - Н. Голуб, М. Греб, Н. Грона, І. Дроздова, К. Климова, О. Копусь, І. Нагрибельна, А. Нікітіна, Л. Овсієнко, А. Попович, Т. Симоненко, М. Цуркан та ін. (і це лише докторські дисертації з української лінгводидактики!)), а педагоги/вчителі/викладачі-практики впровадити їх під час навчання, тим глибшою стає проблема осмислення назв, переваг, недоліків, особливостей застосування, психологічних характеристик, алгоритмів дії, результативних показників, критеріїв розрізнення, ефективності тощо. Зазначене вище зумовлено тим, що проблема методів надзвичайно багатоаспектна, а отже, значна кількість питань залишається недостатньо дослідженою, тим більше в умовах відкритості й адаптації освіти до швидко змінюваних вимог суспільства. Актуальними сьогодні, зокрема, залишаються проблеми диференціації методів і прийомів навчання та добір методів навчання, що сприяють формуванню у здобувачів освіти компетентностей, потрібних для успішної самореалізації у житті.

Мета статті - привернути увагу науковців $\mathrm{i}$ практиків до не досить «популярного» сьогодні методу моделювання комунікативних ситуацій, що в сукупності з іншими методами/прийомами уможливлює формування в здобувачів освіти життєвих компетентностей; на конкретних прикладах розкрити особливості широкого застосування методу та обгрунтувати переваги його в процесі підготовки майбутніх педагогів/учителів/викладачів до фахової діяльності.

Виклад основного матеріалу дослідження. Як відомо, складником кожного методу є прийом навчання. Межі між поняттями «метод» і «прийом» досить мінливі, інколи їх ототожнюють або ж використовують як цілісний термін. Методи навчання та методичні прийоми можуть змінювати один одного в конкретних педагогічних ситуаціях. Одні й ті самі методичні прийоми можуть бути використані в різних методах. I навпаки, один і той самий метод може містити різні прийоми. У контексті зазначеного вище нам імпонує твердження О. Кучерук про те, що «з теоретичного погляду метод і прийом навчання означають одне й те саме - спосіб. Їх специфіка має функціональний характер, у процесі функціонування між способами навчання виявляються відношення допоміжності. За таких умов допоміжні методи виступають елементарними прийомами у складі основних методів. Використання термінів «основний метод» і «допоміжний метод» дає змогу не протиставляти методи і прийоми, а розглядати їх як взаємопов'язані способи навчання, що разом становлять цілісну систему методів» [3, с. 87]. Саме тому в дослідженні послуговуємося термінологією, запропонованою О. Кучерук.

Основним методом навчання в процесі підготовки майбутніх вчителів/викладачів/педагогів до фахової діяльності вибираємо метод моделювання комунікативних ситуацій, оскільки він, на наше переконання, орієнтує здобувачів освіти на розвиток життєвих компетентностей та соціальної інтеграції. Означений метод скерований: 1) активізувати мовлення здобувачів освіти; 2) спонукати бажання й сформувати вміння вступати в мовленнєвий контакт 3 іншими, досвід швидко орієнтуватися в невизначеному, непрогнозованому перебігові комунікації; 3) самостійно застосовувати комунікативний досвід в інших сферах життєдіяльності; 4) розвинути культуру фахового мовлення педагога та ін. Усього вищезазначеного можливо досягти за належної комунікативної практики у процесі розв'язання завдань, що моделюють реальні життєві, зокрема фахові, проблемні ситуації.

Звернемо увагу на те, що метод моделювання комунікативних ситуацій уможливлює сформувати загальні й професійні компетентності, визначені чинними Професійними стандартами для групи професій «Вчитель початкових класів закладів загальної середньої освіти», «Вчитель закладу загальної середньої освіти», «Вчитель початкової освіти (з дипломом молодшого спеціаліста)» [5], «Викладач закладів вищої освіти» [4], «Педагог професійного навчання» [6]. Наприклад: ЗК - «здатність адаптуватися до умов освітнього середовища», «здатність нести персональну відповідальність за результати прийняття професійних рішень», «здатність до комунікацій у межах професійної діяльності», «здатність діяти в нестандартних ситуаціях», «здатність запобігати конфліктним ситуаціям» [6]; ЗК - «здатність до міжособистісної взаємодії, роботи в команді, спілкування з представниками інших професійних груп різного рівня», ПК: «здатність розвивати мовно-комунікативні уміння та навички учнів», «здатність конструктивно та безпечно 
взаємодіяти 3 учасниками освітнього процесу», «здатність до суб'єкт-суб'єктної (рівноправної та особистісно зорієнтованої взаємодії з учнями в освітньому процесі», «здатність взаємодіяти 3 іншими вчителями на засадах партнерства та підтримки (у рамках наставництва, супервізії тощо)» [5]; 3К - «володіння комунікативними навичками, здатність проявляти емпатію», «здатність діяти на основі етичних міркувань (мотивів)», «здатність проявляти толерантність та повагу до культурної різноманітності», «здатність діяти соціально відповідально та свідомо» [4].

Для кожної із зазначених вище компетентностей необхідними $є$ вміння доречно, виразно й дохідливо висловлювати й аргументовано доводити власну думку (усно і письмово); критично аналізувати ситуацію та моделювати різні шляхи iii розв'язання; правильно оцінювати власні та чужі емоції, конструктивно реагувати на них та досягати комунікативної взаємодії у процесі педагогічної співпраці тощо.

Для підготовки висококваліфікованих учителів/викладачів/педагогів уважаємо цінними i практично значущими $y c i$ схарактеризовані в працях учених-дидактів і лінгводидактів методи навчання. Однак пріоритетними для формування зазначених вище компетентностей і вмінь уважаємо: основний - моделювання комунікативних ситуацій; допоміжні - інструктажу, гіпотез, прогнозування, бесіди, імітаџійний, смислового бачення й аргументування, аналогії, класифікації, демонстрачії відеоматеріалів, спостереження, діалогування, дискусії. Унаочнимо особливості широкого застосування їх у процесі підготовки майбутніх педагогів/учителів/викладачів до фахової діяльності на прикладі викладання дисциплін «Комунікативні процеси в педагогічній діяльності» та «Культура професійного мовлення», що можуть бути як обов'язковими, так і вибірковими компонентами для здобувачів освіти, які отримують кваліфікацію вчителя/викладача/педагога (за спеціалізаціями).

Під час вивчення теми «Комунікативний аспект культури мовлення вчителя: ситуативна конкретність» (дисципліна «Культура професійного мовлення») пропонуємо для аналізу типові життєві ситуації, що потребують використання методу моделювання комунікативних ситуацій, як-от:

Ситуація 1. Викладач зайшов до аудиторії та побачив на підлозі недопалок. «Чий це?» - запитав він. «Ваш, - відповів один із найсміливіших присутніх. - Ви його першим побачили».

\section{Завдання:}

1. Визначте морально-етичні норми поведінки суб'єктів педагогічного спілкування.

2. Змоделюйте комунікативну ситуацію, у якій мовленнєва поведінка викладача залежала б:
- від поганого настрою чи моменту роздратування;

- здорового глузду й розумної лінії поведінки;

- почуття гумору.

Ситуація 2. Пролунав дзвінок, усі здобувачі освіти здали викладачеві зошити 3 письмовими роботами й вийшли 3 аудиторії. Залишився один, який продовжував писати, радше, списувати 3 телефону. До нього підійшов викладач.

- Може, досить? - запитав він.

Юнак підвів очі й відповів:

- У мене розпал творчого натхнення.

- Творчого списування?

- А хоч би й так... Можливо, саме у цьому моя індивідуальність?

- Годі! Здавайте Вашу роботу та йдіть відпочивати.

- А як же диференційований підхід до навчання? Нас навчали...

Викладач зупиняє студента.

- Чого вас навчали, мені відомо, однак зараз на цю тему дискутувати не будемо.

- Це не демократично!

Викладач підвищує голос:

- Дивно Ви розумієте демократію!

Юнак, голосно і сердито:

- А ось кричати не варто!

Викладач, роздратовано:

- Та як на тебе не кричати!

Юнак:

- Зумійте вчасно зупинитися!

Завдання:

1. Схарактеризуйте усне мовлення суб' єктів $i$ використовувані ними мовні й немовні знаки.

2. Змоделюйте комунікативну ситуацію, щуо дала б можливість учасникам діалогу завериити розмову, але так, щьоб зняти напругу $i$ створити ситуацію відкритості. Які мовні $\check{u}$ немовні знаки будуть найбільи доречними? Обгрунтуйте думку.

Оскільки неможливо аналізувати ту чи ту комунікативну ситуацію з опертям на будь-який метод у «чистому вигляді», викладач акцентує увагу на методові моделювання комунікативних ситуацій як основному, допоміжними ж вибирає такі:

- метод інструктажу, метод гіпотез, метод прогнозування - перед виконанням завдань здобувачі отримують інструктаж щодо їх виконання й оцінювання, під час якого мають усвідомити, що єдино можливого вирішення немає й не може бути, тому всі відповіді будуть різнитися, оцінювання їх залежатиме від наявності кількох можливих припущень (гіпотез) і прогнозування альтернативних варіантів вирішення тієї чи тієї конфліктної ситуації;

- бесіди й діалогування - у процесі обговорення тих чи тих відповідей; 
- імітаиійний - під час розігрування окремих комунікативних ситуацій, що уможливить усвідомлення студентами неможливості 100\%-го «вгадування» чи прогнозування відповіді співрозмовника: змоделювати можна, але в реаліях вона може бути протилежною, тому в стрімко змінюваних умовах перебігу комунікативного процесу ми маємо «перемоделювати» і власну комунікативну поведінку, дібрати інші мовні й немовні засоби задля досягнення поставленої комунікативної мети;

- метод смислового бачення й аргументування - відповідь студентів залежить від того, який смисл (емоційний, логічний, простий, складний, глибинний чи поверховий) вони вбачають у тій чи тій ситуації, від чого, своєю чергою, залежить добір вербальних і невербальних засобів задля мовного оформлення переконливих аргументів, що будуть вибрані для вибору різних шляхів вирішення одного й того самого конфлікту.

Особливості застосування методу моделювання комунікативних ситуацій у взаємозв'язку з іншими (допоміжними) методами під час вивчення теми «Розв'язання та усунення педагогічних конфліктів» (дисципліна «Комунікативні процеси в педагогічній діяльності») унаочнимо схематично:

\section{Завдання:}

1. Змоделюйте комунікативну ситуацію, завдяки якій би відбулося:

1) вирішення проблеми, щзо стала причиною його виникнення;

2) досягнення компромісу, що базується на взаємних розумних учинках;

3) поступове згладжування протиріч.

2. Підготуйте короткий виступ (на 5 хв.), у якому просто, зрозуміло й добре аргументовано переконайте співрозмовника-«опонента»:

1) або в тому, щчо розв'язання чи врегулювання конфлікту - наслідок ефективної комунікаиії саме учасників конфлікту, а втручання інших може лише погіршити ситуацію;

2) або ж навпаки.
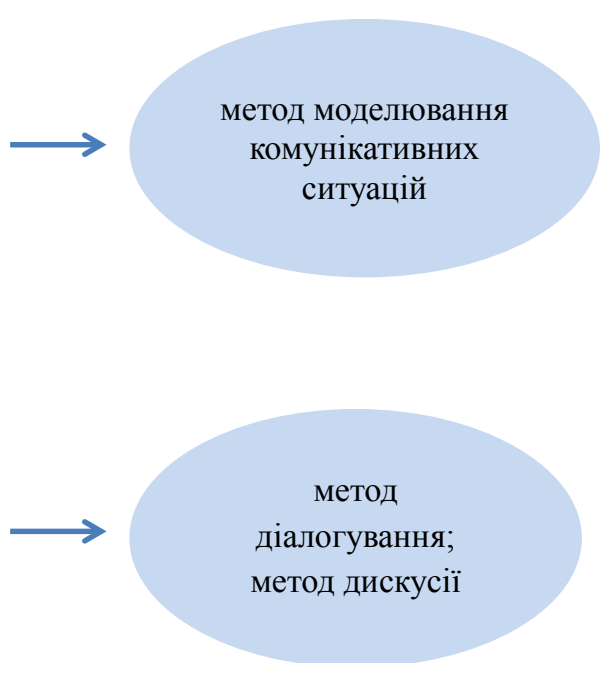

Додаток 2

\section{Завдання:}

1. Перегляньте відеофрагмент кілька разів. Змоделюйте мовленнєву поведінку учасників конфлікту, за якої:

1) його можливо було б уникнути;

2) можна було б залагодити шляхом досягнення компромісу.

2. Дайте характеристику конфлікту за характером взаємодії, за ознаками вияву, за типом вирішення, за змістом, за кінцевим результатом, залежно від напряму комунікаиіі, за кількістю осіб, які беруть у ньому участь.

3. Спрогнозуйте перебіг конфлікту, якще припустити, що ситуачія унаочнює явище мобінгу.
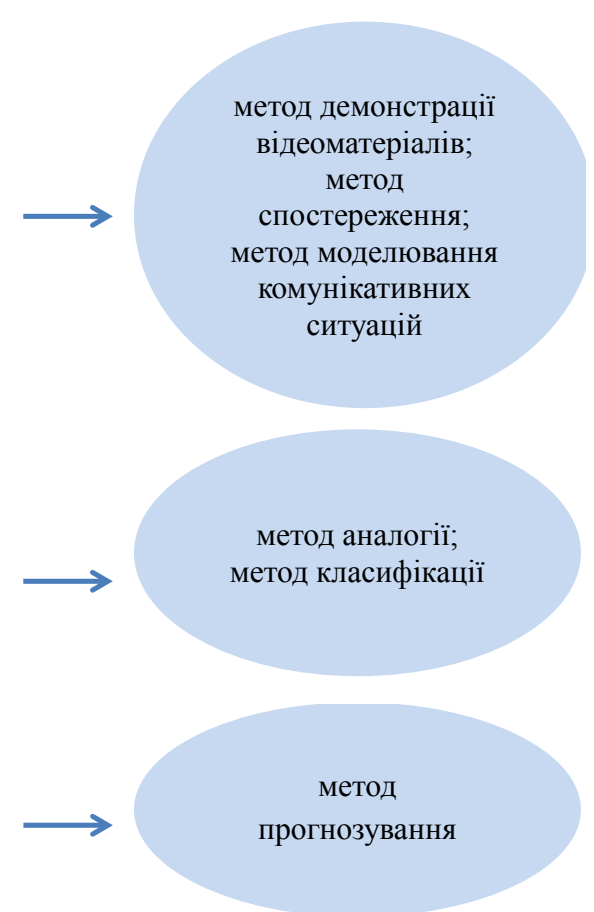
Ситуація 1. Проаналізуйте комунікативну ситуацію. Два вчителя розмовляють, стоячи біля вікна. Один 3 них - молодший, інший - старший. Лунає дзвінок, із класу виходить учитель середніх років, підходить до колег i, зарозуміло «окинувши поглядом» молодого, подає руку старшому й починає з ним розмову (див. Додаток 1).

Ситуація 2. Перегляньте відео за покликанням https://www.youtube.com/watch? $v=66 B L U 5$-BadA (уривоквипускуновин ТСНна каналі 1+1). Проаналізуйте комунікативну ситуацію (див. Додаток 2).

Виконання завдань, що моделюють життєві, зокрема й фахові, комунікативні ситуації, спонукають здобувачів освіти до аналізу фактів і явищ дійсності, активної мовленнєвої та пізнавальної діяльності. Ми не випадково виокремили курсивом «активної», оскільки інколи робота 3 активізації мовлення здобувачів освіти викликає у вчителів/викладачів/педагогів відчуття витрачених марно зусиль.

Цьому є пояснення. По-перше, слова, відповідно до своїх значень, посідають у пам'яті або центральне місце (ті, якими ми часто послуговуємося в комунікативній практиці), або периферійне (усі інші). Як правило, здобувачі освіти вибирають перші, уважаючи, що їх достатньо для побудови висловлення, хоча ті, які перебувають на периферії, можуть зробити висловлення яскравішим, динамічнішим, точнішим, дають можливість легше досягати комунікативної мети тощо. Отже, маємо зацікавити здобувачів освіти поекспериментувати з вибором і сформувати відповідні навички. По-друге, залучити частину здобувачів освіти до активного мовлення складно, оскільки схильність до мовчання може бути особливістю темпераменту особистості, а може свідчити про нерозуміння предмета мовлення, значення слів, що використовує співрозмовник, недостатній рівень практики мовлення, що провокує побоювання висловитися.

Досвід нашої педагогічної діяльності засвідчив: якщо під час навчання акцентувати увагу не лише на відтворенні теорії у процесі виконання завдань, а «змусити», спонукати здобувачів освіти говорити, то процес вибору слів (із центру й периферії лексикону) прискорюється, автоматизується, добір мовних засобів стає свідомим, обгрунтованим, виваженим. Спочатку здобувач, добираючи слова, говорить повільно, виважено, ніби трохи затинається, існує розрив у часі між формуванням змістового боку висловлення і його мовним наповненням, надалі цей розрив стає усе більш незначним відповідно до того рівня мовленнєвого розвитку й комунікативного досвіду, якого досягає здобувач освіти у процесі навчання.

Висновки. Так, із часом у процесі систематичного виконання завдань, що моделюють життєві, зокрема й фахові, реалії, за використання методу моделювання комунікативних ситуацій як основного у взаємозв'язку з допоміжними (у нашому дослідженні - методи інструктажу, гіпотез, прогнозування, бесіди, імітаційний, смислового бачення й аргументування, аналогії, класифікації, демонстрації відеоматеріалів, спостереження, діалогування, дискусії) здобувачі освіти, по-перше, долають страх виступу перед аудиторією (оскільки обговорення тієї чи тієї ситуації відбувається щоразу в групі за наявності протилежних поглядів на вирішення певної проблеми); активізують мовлення; автоматизують орієнтування у невизначеному, непрогнозованому перебігові комунікації; уможливлюють набуття комунікативного досвіду; підвищують рівень культури фахового мовлення; по-друге, розвивають такі операції мислення, як аналіз, синтез, порівняння, абстрагування, узагальнення, систематизація, конкретизація, простеження зв'язків, класифікація; по-третє, стимулюють креативність тощо.

Перспективою подальших розвідок убачаємо пошуки шляхів формування життєвих компетентностей здобувачів освіти, майбутніх учителів/ викладачів/педагогів, засобами сучасних технологій навчання, зокрема технологій навчання української мови.

\section{ЛІТЕРАТУРА}

1. Голуб Н.Б. Підходи до навчання української мови в основній школі. Украӥнська мова і література в школі. 2015. № 3(155). С. 2-10.

2. Кулик О.Д., Рубан І.В. Мовна й мовленнєва особистість: проблема дефініцій. Теоретична і дидактична філологія. 2014. Вип. 17. С. 76-89.

3. Кучерук О.А. Система методів навчання української мови в основній школі : монографія. Житомир : ЖДУ, 2011. 420 с.

4. Професійний стандарт на групу професій «Викладач закладів вищої освіти», 2021. URL: https://cutt.ly/TveShRK (дата звернення: 27.03.2021).

5. Професійний стандарт на групу професій «Вчитель початкових класів закладів загальної середньої освіти», «Вчитель закладу загальної середньої освіти», «Вчитель початкової освіти (з дипломом молодшого спеціаліста)». 2020. URL: https://cutt.ly/xveSx8D (дата звернення: 27.03.2021).

6. Професійний стандарт на групу професій «Педагог професійного навчання». 2020. URL: https://cutt.ly/KveSmAc (дата звернення: 27.03.2021). 


\section{REFERENCES}

1. Holub N.B. (2015) Pidkhody do navchannia ukrainskoi movy v osnovnii shkoli [Approaches to teaching the Ukrainian language in primary school]. Ukrainian language and literature at school: scientific and methodological journal. № 3 (155). P. 2-10.

2. Kulyk O.D., Ruban I.V. (2014) Movna y movlennieva osobystist: problema definitsii [Linguistic and speech personality: the problem of definition]. Theoretical and didactic philology: a collection of scientific papers. Pereiaslav-Khmelnytskyi: FOP Lukashevych, 2014. Vol. 17. P. 76-89.

3. Kucheruk O.A. Systema metodiv navchannia ukrainskoi movy v osnovnii shkoli [The system of teaching methods for the Ukrainian language in basic school]: monograph. Zhytomyr: Zhytomyr State University, 2011. $420 \mathrm{p}$.

4. Profesiinyi standart na hrupu profesii «Vykladach zakladiv vyshchoi osvity» (2021) [Professional standard for the group of professions «Teacher of higher education institutions»]. URL: https://cutt.ly/TveShRK (access date: 16.03.2021).

5. Profesiinyi standart na hrupu profesii «Vchytel pochatkovykh klasiv zakladiv zahalnoi serednoi osvity», «Vchytel zakladu zahalnoi serednoi osvity», «Vchytel pochatkovoi osvity (z dyplomom molodshoho spetsialista)» (2020) [Professional standard for the group of professions «Elementary school teacher of general secondary education», «Teacher of general secondary education», «Teacher of elementary education (with a diploma of junior specialist)»]. URL: https://cutt.ly/xveSx8D (access date: 16.03.2021).

6. Profesiinyi standart na hrupu profesii «Pedahoh profesiinoho navchannia» (2020) [Professional standard for the group of professions «Teacher of vocational training»]. URL: https://cutt.ly/KveSmAc (access date: 16.03.2021). 